\title{
PENGARUH MODEL PEMBELAJARAN KOOPERATIF TIPE EXAMPLES NON EXAMPLES MENGGUNAKAN MEDIA LABORATORIUM TERHADAP HASIL BELAJAR SISWA 2018
}

\author{
Eni Sumanti Nasution ${ }^{1}$, Wirna Susanti ${ }^{1)}$ \\ ${ }^{1)}$ Fakultas Keguruan dan Ilmu Pendidikan Universitas Graha Nusantara \\ e-mail: enisumanti.nst@gmail.com
}

\begin{abstract}
This study aims to analyze the physics learning outcomes of students by using the coopertive learning model type Non Examples laboratory assisted better than using conventional learning.The research was conducted in a quasi-experimental manner, the population of this study was the tenth grade students of SMAN 1 Tapung Hulu. The sample selection is done by cluster random sampling which is class $X_{2}$ and $X_{1}$. The instrument of this study uses the Learning Outcomes test that has been valid and realistic. The data in this study were analyzed by test. The results showed that there was an effect of student learning outcomes by using Cooperative Learning Example Non Examples laboratory assisted. It could be seen that student learning outcomes increased from 41.85 to 81.68. Student learning outcomes using cooperative learning models Examples Non Examples laboratory assisted are better than conventional learning..
\end{abstract}

Keywords: Models Examples Non Examples, Laboratorium, Learning Outcomes

\begin{abstract}
Abstrak
Penelitian ini bertujuan untuk menganalisis hasil belajar fisika siswa dengan menggunakan model pembelajaran koopertif tipe Example non Examples berbantuan laboratorium lebih baik dibandingkan dengan menggunakan pembelajaran konvensional. Penelitian yang dilakukan secara quasi eksperimen, populasi Penelitian ini adalah siswa kelas X SMAN 1 Tapung Hulu. Pemilihan sampel dilakukan secara cluster random sampling yaitu kelas $\mathrm{X}_{2}$ dan $\mathrm{X}_{1}$. Instrumen penelitian ini menggunakan tes Hasil Belajar yang telah valid dan realibel.. Data dalam penelitian ini dianalisis dengan Uji t. Hasil penelitian menunjukkan bahwa Terdapat pengaruh hasil belajar siswa dengan menggunakan pembelajaran Kooperatif Example Non Examples berbantuan laboratorium hal ini dapat dilihat hasil belajar siswa meningkat dari 41,85 menjadi 81,68. Hasil belajar siswa dengan menggunakan model pembelajaran kooperatif Examples Non Examples berbantuan laboratorium lebih baik dibandingkan dengan pembelajaran konvensional.
\end{abstract}

Kata Kunci: Model Examples Non Examples, Laboratorium, Hasil Belajar.

\section{PENDAHULUAN}

Kecenderungan pendidikan pembelajaran di Indonesia secara umum dalam kurikulum dan model pembelajara adalah masih dominan pembelajaran konvensional dan kurang variatifnya model pembelajaran yang diterapkan oleh guru sehingga hanya terjadi komunikasi satu arah dan ilmu di transfer secara cepat dari guru kepada siswa secara rill. Hal ini yang membuat daya serap siswa lemah karena hanya mendengarkan dari guru.

Sehingga diperlukan perubahan paradigma pembelajaran dari yang berpusat pada guru ke yang berpusat pada siswa. Hal ini dapat membuat siswa lebih proaktif untuk membangun pengetahuannya sendiri melalui pengalaman belajar dan interaksi dengan lingkungan. Dalam 
kegiatan belajar mengajar disebut dengan pembelajaran yang menitikberatkan pada keterlibatan siswa dalam mempelajari sesuatu, tak terkecuali dalam mata pelajaran fisika.

Belajar fisika adalah suatu proses psikologis berupa tindan/upaya seseorang untuk merekonstruksi, memahami suatu gejala alam. Tindakan/upaya yang dimaksudkan adalah pengalaman belajar fisika berupa reaksi orang yang belajar terhadap materi fisika sebagai bahan ajar. Belajar fisika pada dasarkan suatu proses yang diarahkan pada suatu gejala alam yang terjadi.

Banyaknya konsep fisika yang bersifat abstrak yang harus diserap siswa dalam waktu relatif terbatas menjadikan ilmu fisika menjadi satu mata pelajaran yang sulit bagi siswa sehingga banyak siswa gagal dalam belajar. Pada umumnya siswa cenderung belajar dengan hafalan daripada aktif membangun pemahaman mereka sendiri terhadap konsep fisika. Hal ini yang terjadi di sekolah, kurangnya pengetahuan guru mengenai strategi pembelajaran inovatif bagi pelajaran fisika, kurangnya kegiatan praktikum dan masih belum memahami dengan baik cara pelaksanaan model maupun metode pembelajaran yang inovatif.

Berdasarkan hasil wawancara dengan siswa bahwa penggunaan kegiatan laboratorium jarang dilakukan. Disamping itu juga menurut wawancara dengan guru bidang studi yang bersangkutan laboratorium jarang digunakan karena keterbatasan pengetahuan dan keterampilan guru dalam melakukan pembelajaran dengan menggunakan laboratorium, hal lainnya yang menjadi kendala adalah lembar kerja siswa hanya berdasarkan buku paket saja dan tidak ada khusus lembar kerja siswa dalam penggunaan laboratorium.

Seharusnya siswa dilatih berpikir dan membuat konsep berdasarkan pengamatan dan percobaan yang dilakukan melalui pengalaman berinteraksi dengan lingkungan tanpa memandang sesuai atau tidaknya konsep yang dikemukakan siswa dengan buku pegangan. Hal tersebut juga sesuai dengan pendapat Lapono (2008) yang mengatakan bahwa pada prinsipnya, dalam pembelajaran yang mendidik hendaknya berlangsung sebagai proses atau usaha yang dilakukan peserta didik untuk memperoleh suatu perubahan tingkah laku sebagai hasil pengalaman individu beriteraksi dengan lingkungannya. Oleh karena itu, guru seharusnya kreatif dan inovatif dalam menerapkan berbagai model mengajar dalam upaya meningkatkan kualitas pembelajaran sehingga mampu memenuhi keperluan pembelajaran untuk setiap siswanya.

Salah satu model pembelajaran yang dapat mengaktifkan siswa adalah model “Cooperatif Learning” (pembelajaran kooperatif). Pembelajaran kooperatif adalah metode pembelajaran berkelompok, sehingga dapat mengaktifkan siswa sebab dalam kelompok mereka diharapkan dapat bekerja sama dan berdiskusi menyelesaikan tugas-tugas yang diberikan guru. Siswa pandai akan membimbing temannya yang lemah, karena keberhasilan kelompok ditentukan oleh keberhasilan masing-masing anggota kelompok dalam menyumbang nilai untuk kelompok (Suyatno, 2009).

Salah satu bentuk pembelajaran kooperatif adalah Examples Non Examples (model pembelajaran menggunakan contoh dan bukan contoh). Model pembelajaran ini menempatkan siswa ke dalam kelompok-kelompok kecil yang heterogen, dimana pembelajaran disajikan dalam bentuk gambar, diagram atau tabel yang sesuai dengan materi bahan ajar dan kompetensi dasar. Selain itu salah satu cara penyampaian materi yang dapat menjembatani antara konsep yang abstrak dan real adalah dengan menggunakan alat peraga (Yensy, 2012).

Model pembelajaran kooperatif dengan tipe examples non examples dapat meningkatkan hasil belajar siswa karena melibatkan siswa untuk ikut dalam proses penemuan, sehingga dapat meningkatkan pemahaman siswa terhadap suatu konsep yang dipelajari, hal ini sesuai dengan penelitian yang dilakukan Km. Wardika, et al (2014) yang menyatakan bahwa menunjukkan bahwa terdapat pengaruh yang signifikan antara model examples non examples terhadap hasil belajar siswa. 
Pada hakekatnya tujuan penelitian ini adalah mencari jawaban atas masalah-masalah penelitian yang telah dirumuskan. Berdasarkan atas rumusan masalah di atas, maka tujuan yang ingin dicapai dalam penelitian ini adalah untuk menganalisis hasil belajar fisika siswa dengan menggunakan model pembelajaran koopertif tipe Example non Examples berbantuan laboratorium lebih baik dibandingkan dengan menggunakan pembelajaran konvensional.

\section{METODE}

Subjek penelitian siswa-siswi kelas X SMA Negeri 1 Tapung Hulu. Sedangkan metode yang digunakan adalah metode quasi eksperimen, yang melibatkan dua kelompok yaitu kelompok eksperimen dan kelompok kontrol. Teknik pengambilan sampel yang digunakan adalah cluster random sampling..

Rancangan penelitian ini didesain control grup pretes-postes design seperti terdapat dalam Tabel 1.

Tabel 1 Control grup pretes-postes desaign

\begin{tabular}{|l|l|l|l|}
\hline Kelas & Pretest & Perlakukan & Post Test \\
\hline Experimen & $\mathrm{Y}_{1}$ & $\mathrm{X}_{1}$ & $\mathrm{Y}_{2}$ \\
\hline Kontrol & $\mathrm{Y}_{1}$ & $\mathrm{X}_{2}$ & $\mathrm{Y}_{2}$ \\
\hline \multicolumn{4}{|c|}{ Sumber : Arikunto (2010) }
\end{tabular}

Keterangan :

$\mathrm{X}_{1}$ : Perlakuan pada kelas eksperimen yaitu Model Example Non Example

$\mathrm{X}_{2}$ : Perlakuan berupa pada kelas kontrol yaitu konvensional

$\mathrm{Y}_{1}$ : Pretest yang diberikan kepada kelas eksperimen dan kelas kontrol sebelum perlakukan

$\mathrm{Y}_{2}$ : Post test yang diberikan setelah adanya perlakukan pada kelas kontrol dan eksperimen

Teknik pengumpulan menggunakan instrumen penelitian terbagi menjadi dua yaitu: instrumen pembelajaran dan instrumen pengambilan data. Instrumen pembelajaran meliputi silabus mata pelajaran fisika kelas X semester 2, Rencana Pelaksanaan Pembelajaran (RPP), dan Lembar Kerja Siswa (LKS). Sedangkan instrumen pengambilan data meliputi tes hasil belajar siswa.

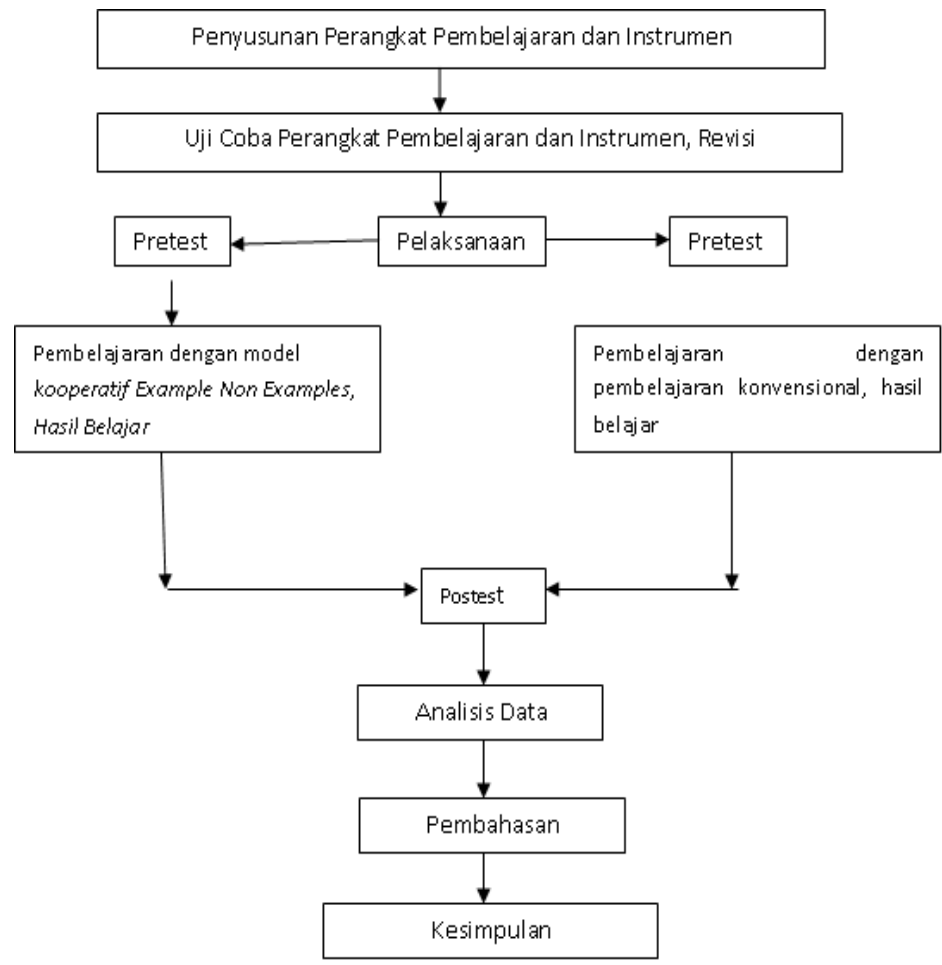

Gambar 1. Bagan alur pelaksanaan penelitian 


\section{HASIL DAN PEMBAHASAN}

Pada penelitian ini, sebelum diberikan perlakuan kepada siswa maka dibuatkan terlebih dahulu pretes kepada siswa baik itu kelas kontrol maupun kelas eksperimen Adapun hasil belajar siswa siswa. didapatkan rata-rata hasil belajar siswa kelas eksperimen adalah 41,85 dan kelas kontrol 45,02. Standar deviasi kelas eksperimen 12,36 dan kelas kontrol 12,15. Adapun dalam pengujian hipotesis penelitian eksperimen maka syaratnya adalah harus normal dan homogen. Adapun melalui uji Normalitas pretes hasil uji normalitas data pada kelas eksperimen dan kelas kontrol didapatkan nilai untuk tes awal untuk eksperimen adalah 0,196 dan kelas kontrol adalah 0,196, karena nilai signifikan kedua kelas lebih besar dari 0,05, maka dapat dikatakan bahwa kelas kontrol dan kelas eksperimen berdistribusi normal.

Uji homogenitas pretes dengan menggunakan Levene’s tes. 0,911 > dari 0,05, maka dapat disimpulkan bahwa siswa kelas kontrol dan kelas eksperimen berasal dari populasipopulasi yang mempunya varians yang sama, atau kedua kelas tersebut homogen.untuk melihat kemampuan siswa maka digunakan uji t diperoleh nilai signifikan (sig 2-arah) dengan uji t adalah 0,25 , karena nilai signifikannya lebih besar dari 0,05 maka $H_{0}$ diterima atau hasil belajar siswa pada tes awal (pretes) kedua kelas tersebut tidak berbeda atau sama secara signifikan.

Adapun langkah selanjutnya dengan untuk data postes pada penelitian diperoleh hasil belajar siswa siswa dikelas eksperimen setelah diberikan perlakuan adalah 81,71 dengan standar deviasi 10,76 dan untuk kelas kontrol rata-rata adalah 73,54 dan standar devias adalah 10,52. Berdasarkan hasil uji normalitas (postes) untuk kelas kontrol adalah 0,075>0,05 dan kelas Kooperatif Example Non Examples adalah 0,053>0,05. Karena nilai signifikansi kedua kelas > 0,05 maka dapat dikatakan bahwa kelas kontrol dan kelas eksperimen berdistribusi normal. Adapun uji homogenitasnya adalah dengan menggunakan uji Levene nilai signifikansinya adalah 0,955. Karena nilai signifikansinya > 0,05 maka dapat disimpulkan bahwa siswa kelas kontrol dan kelas eksperimen berasal dari populasi yang mempunyai varians yang sama, atau kedua kelas tersebut homogen.

Adapun langkah selanjutnya untuk melihat pengaruh model pembelajaran kooperatif examples non examples terhadap hasil belajar menggunakan uji t maka diperoleh data signifikan lebih kecil dari 0,05 maka hipotesis diterima. Dari hasil perhitungan dengan SPSS 21 diperoleh signifikan 0,001 ini berarti bahwa lebih kecil dari 0,05 maka ada perbedaan hasil antara kelas kontrol dan kelas eksperimen, dimana kelas eksperimen lebih baik daripada kelas kontrol dengan ini dapat atau dapat dikatakan bahwa dengan menggunakan model pembelajaran kooperatif Example Non Examples memberikan pengaruh terhadap hasil belajar siswa.

Model examples non examples merupakan salah satu pendekatan Group investigation dalam pembelajaran kooperatif yang dirancang untuk mempengaruhi pola interaksi siswa dan meningkatkan perolehan hasil akademik. "Tipe pembelajaran ini dimaksudkan sebagai alternatif terhadap model pembelajaran kelas tradisional dan menghendaki siswa saling membantu dalam kelompok kecil dan lebih dicirikan oleh penghargaan kooperatif daripada individu” (Ibrahim, 2000).

Model pembelajaran examples non examples berbantuan laboratorium dapat meningkatkan hasil belajar siswa dibandingkan dengan pembelajaran konvensional, . Adapun nilai hasil belajar siswa kelas eksperimen meningkat dari pretes ke postest yaitu dari nilai ratarata 41,85 menjadi 81,68 dan kelas kontrol dari 45 menjadi 73,5. Hal ini dapat dilihat bahwa nilai hasil belajar dengan menggunakan model kooperatif tipe examples non examples berbantuan laboratorium lebih tinggi dibandingkan dengan model pembelajaran konvensional. Hal ini dapat dilihat pada Gambar 2.

Berdasarkan hasil penelitian ini dapat disimpulkan bahwa dengan menggunakan model pembelajaran kooperatif examples non examples berbantuan laboratorium lebih baik 
dibandingkan dengan kelas pembelajaran konvensional dalam meningkatkan hasil belajar siswa hal ini sesuai dengan penelitian yang dilakukan oleh Yensy (2012) yang menyatakan terjadinya peningkatan yang cukup berarti antara kelas pembelajaran konvensional dengan kelas yang diberi perlakuan. Dilihat dari nilai-nilai siswa tiap siklus dan tercapainya ketuntasan belajar klasikal maka penerapan model pembelajaran kooperatif tipe Example Non Example menggunakan alat peraga pada pokok bahasan kubus dan balok dapat dikatakan meningkatkan hasil belajar siswa kelas VIII SMP N 1 Argamakmur.

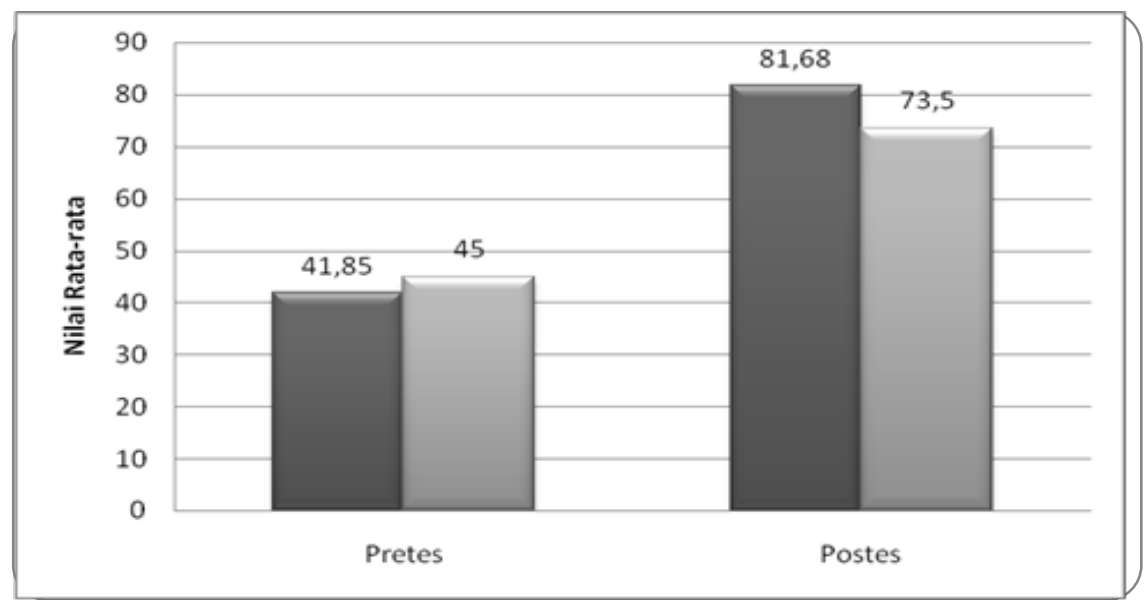

Gambar 2 Hasil Pretes dan Postest

Selanjutnya dikarenakan nilai rata-rata siswa setiap siklus meningkat dan ketuntasan belajar siswa tercapai maka penerapan model pembelajaran kooperatif tipe Example Non Example ini dikatakan berhasil. hal ini disebabkan karena siswa lebih aktiv dalam menemukan konsep-konsep fisika hal ini sesuai dengan penelitian yang dilakukan oleh Susanti (2014) yang menyatakan Model examples non examples adalah suatu model pembelajaran yang menggunakan gambar yang sesuai dengan kompetensi dasar. Example Non example adalah teknik yang dapat digunakan untuk mempercepat penguasaan konsep siswa. Model ini bertujuan untuk mempersiapkan siswa secara cepat dengan menggunakan 2 hal yang terdiri dari example dan non-example dari suatu definisi konsep yang ada, dan meminta siswa untuk mengklasifikasikan keduanya sesuai dengan konsep yang ada.

Pelaksanaan penelitian berlangsung masing-masing 3 kali pertemauan pada kelas eksperimen maupun kelas kontrol berdasarkan 3 buah rencana pelaksanaan pembelajaran (RPP) yang telah dirancang pada saat sebelum penelitian dilakukan. Pada kelas eksperimen peneliti menerapkan model pembelajaran Kooperatif examples non examples sedangkan pada kelas kontrol peneliti menerapkan pembelajaran konvensional. Penerapan model pembelajaran Kooperatif Tipe Example Non Examples ditujukan untuk melihat ada atau tidaknya perbedaan hasil belajar siswa pada kelas eksperimen.

Penerapan model pembelajaran Kooperatif Example Non Examples di kelas eksperimen dimulai dengan membentuk kelompok siswa menjadi 5 kelompok dengan masingmasing kelompok terdiri dari 8 orang siswa. kemudian guru memberikan demonstrasi materi suhu dan kalor..

Dari nilai rata-rata keterampilan siswa diperoleh bahwa nilai siswa yang melakukan model pembelajaran kooperatif examples non examples dengan berbantuan laboratorium sudah dapat mengaplikasi dalam melakukan praktikum dengan dilihat tinggi nilai rata-rata siswa terutama dalam mempersiapkan alat karena dalam tahapan model ini siswa dituntun lebih aktiv untuk menemukan konsep-konsep fisika. Untuk membangun nilai afektif dapat dilihat dengan mengoraganisasikan karena disini dilihat bagaimana kerja sama dan keatifan siswa dalam melakukan percobaan. Dengan melakukan praktikum dapat meningkatkan minat belajar siswa 
hal ini sesuai dengan penelitian yang dilakukan oleh Habibah (2016) Pelaksanaan proses pembelajaran dengan menggunakan media pembelajaran menyebabkan guru mampu mengefektifitaskan penggunaan media gambar. Gambar pada dasarnya membantu mendorong para siswa dan dapat membangkitkan minatnya pada pembelajaran. Dalam penelitian ini telah terbukti bahwa media gambar dapat meningkatkan prestasi belajar siswa.

\section{KESIMPULAN}

Adapun kesimpulan yang dapat diperoleh dari hasil penelitian ini adalah 1) terdapat pengaruh hasil belajar siswa dengan menggunakan pembelajaran Kooperatif Example Non Examples berbantuan laboratorium hal ini dapat dilihat hasil belajar siswa meningkat dari 41,85 menjadi 81,68, 2) Hasil belajar siswa dengan menggunakan pembelajaran kooperatif Examples Non Examples berbantuan laboratorium lebih baik dibandingkan dengan pembelajaran konvensional.

Adapun saran dari peneliti adalah (1) Peneliti selanjutnya menggunakan jangka waktu yang lebih lama karena waktu yang tersedia dalam pelaksanaan pembelajaran baik dibelajarkan dengan menggunakan model pembelajaran Kooperatif Example Non Examples dan dibelajarkan dengan pembelajaran ekspositori masih sangat kurang, sebab disesuaikan dengan jadwal sekolah yang bersangkutan, (2) Pendidik hendaknya memilih model pembelajaran yang sesuai, dengan tujuan pembelajaran. Dilihat dengan karakter siswa, siswa belum terbiasa dengan menggunakan model pembelajaran Kooperatif Example Non Examples, maka sebaiknya siswa mulai dilatih untuk melakukan percobaan-percobaan sederhana ketika pembelajaran fisika agar memiliki respon yang cepat akan melakukan model pembelajaran Kooperatif Example Non Examples, (3) untuk peneliti selanjutnya dapat mengalokasi waktu yang lebih banyak sehingga pelaksanaanya lebih optimal.

\section{DAFTAR PUSTAKA}

Habibah, Syarifah. 2016. Penggunaan Model Pembelajaran Examples Non Examples Terhadap Ketuntasan Hasil Belajar Siswa Pada Materi Tokoh-Tokoh Pergerakan Nasional Kelas V SDN 70 Banda Aceh. Jurnal Pesona Dasar No Vol.4 No.3.

Ibrahim. Muslimin. 2000. Model-Model Pembelajaran. Jakarta Rineka Cipta.

Lapono, N. 2008. Belajar dan Pembelajaran SD. Jakarta: Direktorat Jenderal Pendidikan Tinggi Departemen Pendidikan Nasional.

Km. Wardika, Md. Sulastri, Kt. Dibia. 2014. Pengaruh Model Examples Non Examples Terhadap Hasil Belajar IPA Siswa Kls V SD Di Gugus III Kecamatan Tampaksiring .e-Journal Mimbar PGSD Universitas Pendidikan Ganesha Vol. 2 No.1.

Nurul Astuty Yensy. B. 2012. Penerapan Model Pembelajaran Kooperatif Tipe Examples Non Examples Dengan Menggunakan Alat Peraga Untuk Meningkatkan Hasil Belajar Siswa Di Kelas VIII SMP N 1 Argamakmur. Jurnal Exacta, Vol. X No. 1.

Suharsimi, Arikunto. 2010. Prosedur Penelitian Suatu Pendekatan Praktik. Jakarta : Rineka Cipta.

Susanti, R. 2014. Pembelajaran Model Examples Non Examples Berbantuan Powerpoint Untuk Meningkatkan Hasil Belajar Ipa. Jurnal Pendidikan IPA Indonesia Vol 3 No.2.

Suyatno. 2009. Menjelajah Pembelajaran Inovatif. Surabaya : Buana Pustaka. 